\title{
elsevier_ESP_741
}

\section{The role of content and language in content and language integrated learning (CLIL) at university: Challenges and implications for ESP}

Elisabet Arnóa ${ }^{\mathrm{a}} 1$

Guzman Mancho-Barés ${ }^{b, *}$

gmancho@dal.udl.cat

${ }^{a}$ Edifici VG1 (EPSEVG), Despatx 109, Polytechnic University of Catalonia, Av. Víctor Balaguer 1, 08800 Vilanova i la Geltrú, Spain

bDept. English and Linguistics University of Lleida, PI. Victor Siurana 1, 25003 Lleida, Spain

*Corresponding author. Tel.: +34 973703461

${ }^{1}$ Tel.: +34 938967750 .

\section{Abstract}

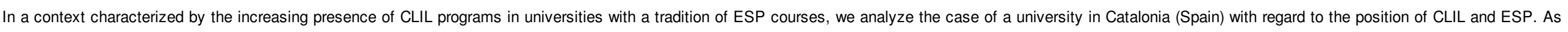

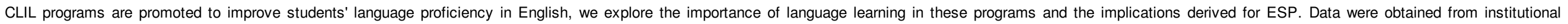

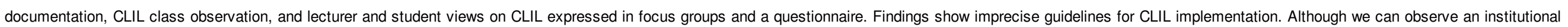

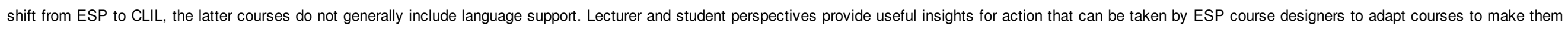

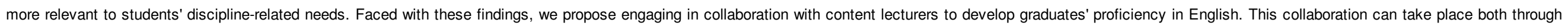
the integration of language in content courses and through the integration of content in ESP courses to make them more relevant to disciplines' communicative needs.

Keywords: CLIL; ESP course reappraisal; Faculty collaboration; Content teachers; ESP teachers

\section{Research background}

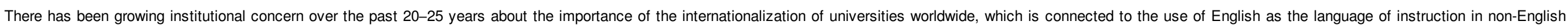

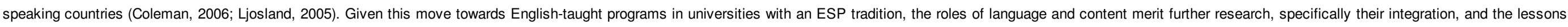
which can be learnt from the ESP perspective to adapt to this new situation.

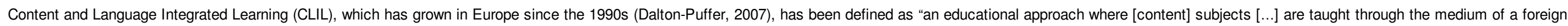

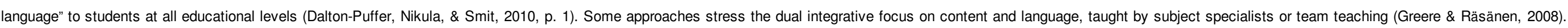

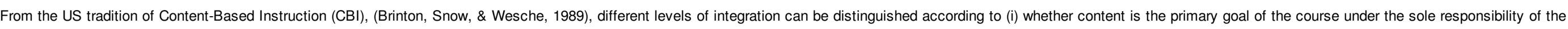

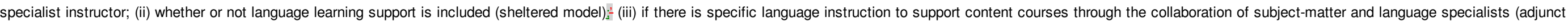

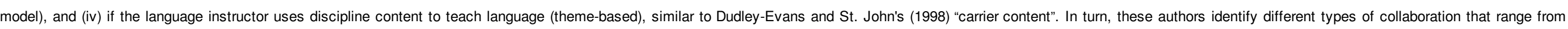

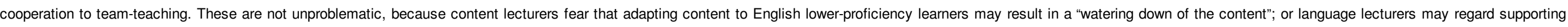
other disciplines as "eroding their professional career" (Crandall \& Kaufman, 2002, p. 3).

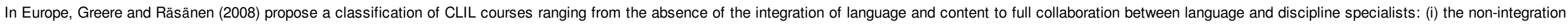

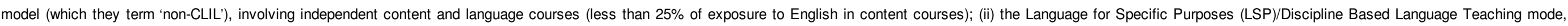

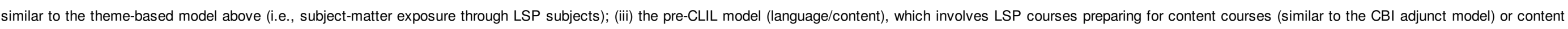




\section{elsevier_ESP_741}

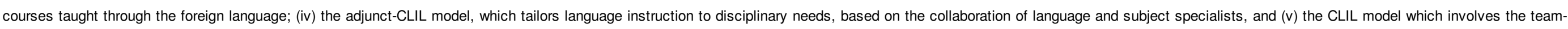
teaching of dual programs catering for language and content. This distinction helps in the analysis of CLIL programs in terms of language and content and the roles played by each.-

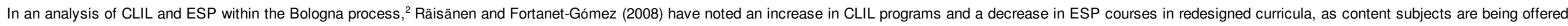

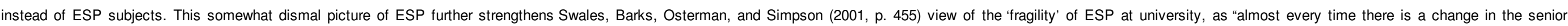

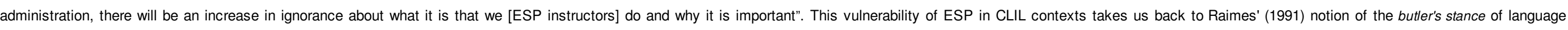
instructors, often being regarded as having a subsidiary role vis-à-vis content instructors.

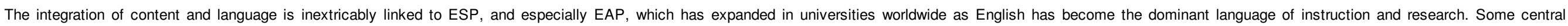

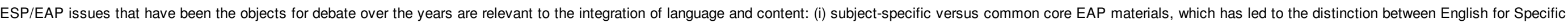

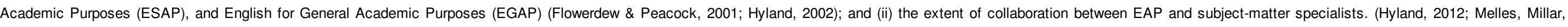
Morton, \& Fegan, 2005; Swales et al., 2001).

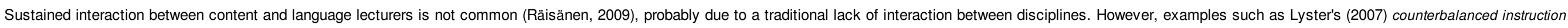

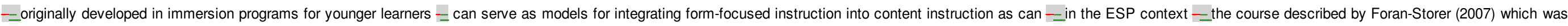
based on cooperative learning and the development of soft skills through authentic discipline-related materials.

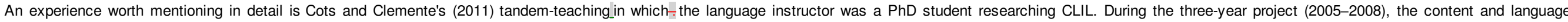

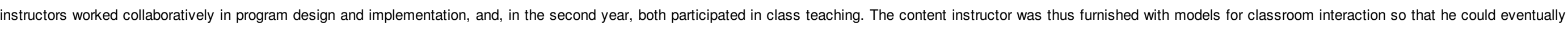
teach the class alone in the last year.

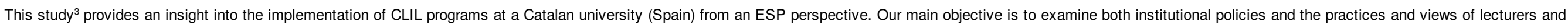

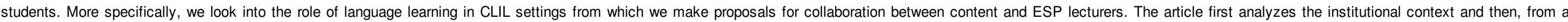

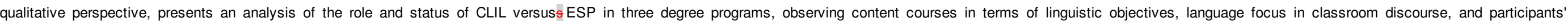

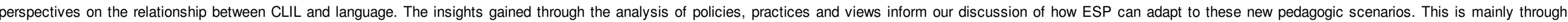
proposing new roles for ESP specialists, encouraging multidisciplinary collaboration, and reappraising the position of ESP courses.

\subsection{Institutional context}

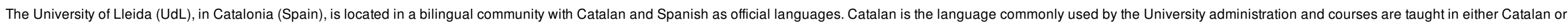

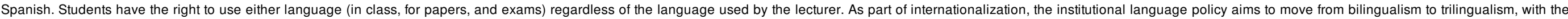

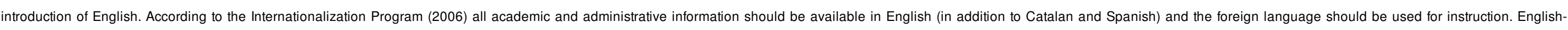

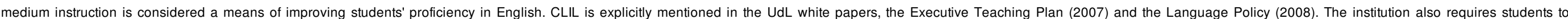

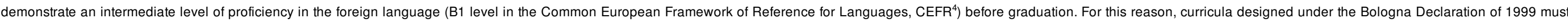

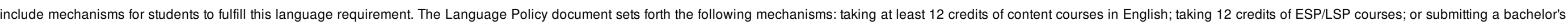

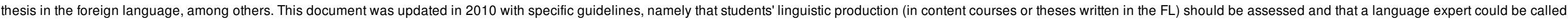

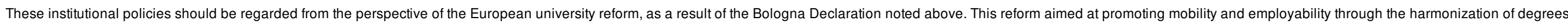

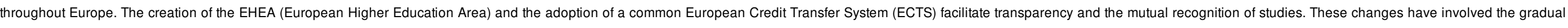

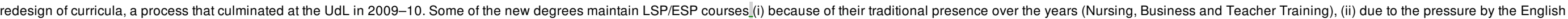

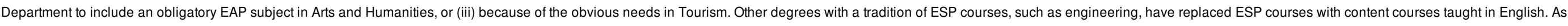

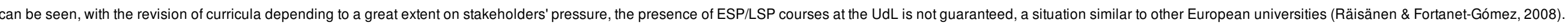




\section{This study}

\subsection{Aims and approach}

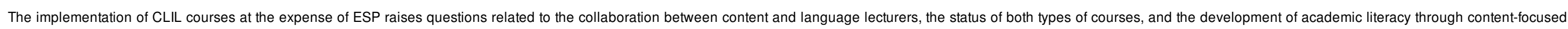

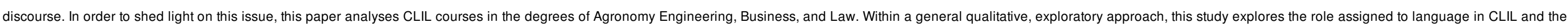
implications that can be derived for ESP/EAP, both for proposing collaboration with content lecturers and for adapting ESP/EAP courses. The specific research questions are as follows:

1. What is the status of CLIL and ESP courses in the three degrees?

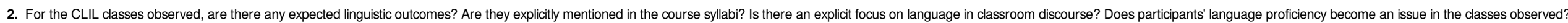

3. What are lecturers' and students' views on the implementation of CLIL, and the role assigned to language? What are their views on CLIL versus ESP?

\subsection{Data and methodology}

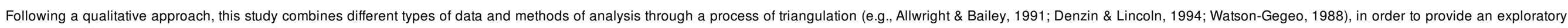

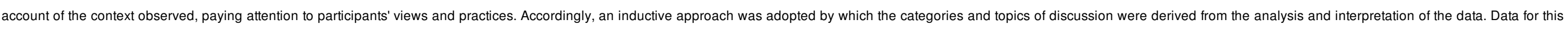

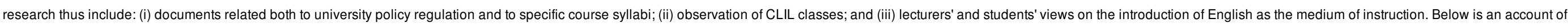
the types of data collected and their focus of analysis.

The documents analyzed included both institutional general white papers regarding language policy (Internationalization Plan, Executive Teaching Plan, Language Policy Plan) and the specific course syllabi for courses observed.

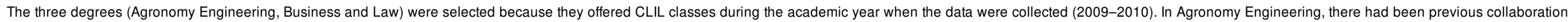

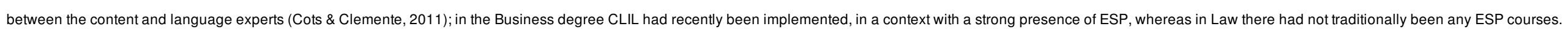

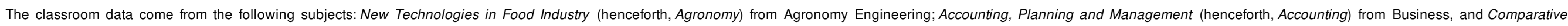
Introduction to Legal Systems (henceforth, Law) from Law. The information about these subjects was obtained from the course descriptions on the websites, and analyzed for the presence or absence of language content.

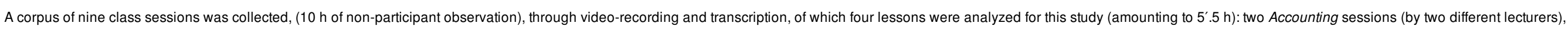

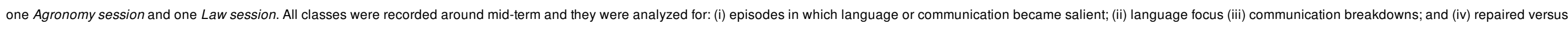
unrepaired language production.

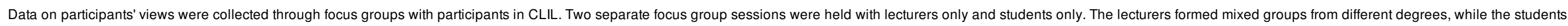

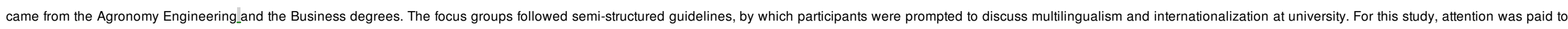
lecturers' and students' views and experience in CLIL. The sessions were video-recorded and transcribed, amounting to almost four hours of data.

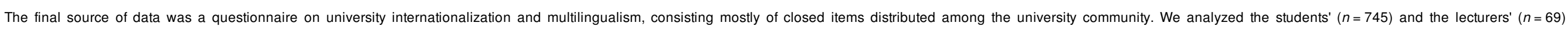

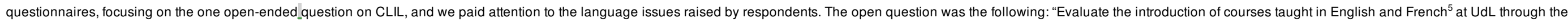

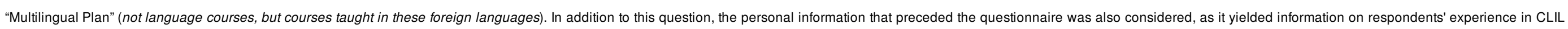
and/or ESP. As opposed to the focus groups and classes, questionnaire respondents had not necessarily been involved in CLIL or ESP.

\section{Findings}

\subsection{Overview of the role of language in the CLIL context}

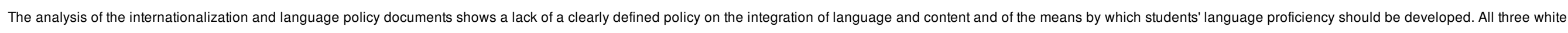

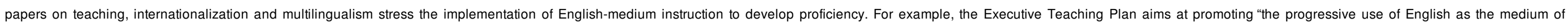




\section{elsevier_ESP_741}

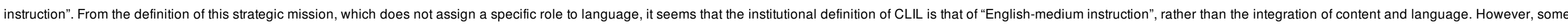
awareness of the role of language appears in the explicit mention of assessing students' language production, although no further guidelines are given apart from the possibility of incorporating a language consultant.

\subsubsection{Course documentation}

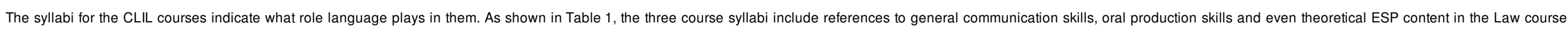
("What is ESP? Why does it exist?" and ESP books, such as Hutchinson \& Waters, 1987).

Table 1 Role of language in the syllabus of CLIL courses.

\begin{tabular}{|c|c|c|}
\hline Subject & Explicit objectives and language learning outcomes & Language support during CLIL classes \\
\hline Accounting & Participate in class discussion and make presentations in English & None \\
\hline Agronomy & Communicate in English, technical vocabulary \& receptive and productive skills & $\begin{array}{l}\text { Collaboration of PhD student/teaching innovation project on CLIL (2005-06 to } \\
2007-08 \text { ) }\end{array}$ \\
\hline Law & ESP theory; reading comprehension and writing. Outcomes: writing \& speaking (oral presentation) & None \\
\hline
\end{tabular}

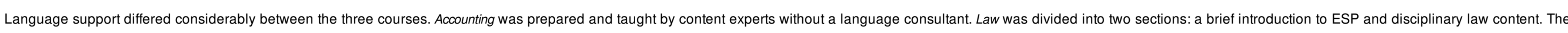

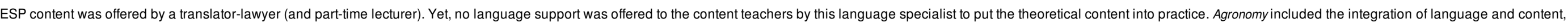
derived from a previous team-teaching experience (Cots \& Clemente, 2011).

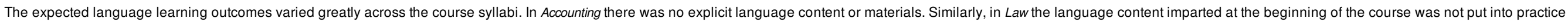

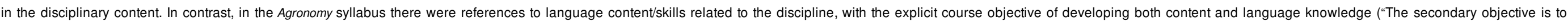
improve your use of English as a technical and professional language").

Therefore, as opposed to Agronomy, in the Accounting and Law courses, language development is either taken for granted as a result of attending classes in English, or else the language component is regarded as theory to be imparted.

\subsection{Role of language in classroom observation}

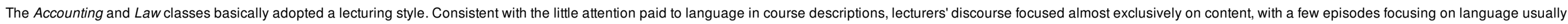
arising out of lecturers' (perceived) low proficiency level or from covert/overt comprehension breakdowns.

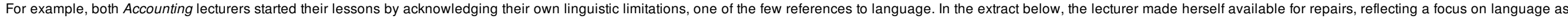
the preview of possible comprehension problems. Moreover, she also admitted that her lack of proficiency and confidence in lecturing in English affected the class methodology and contributed to her use of group work.

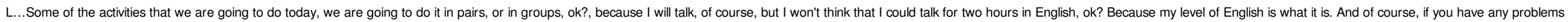

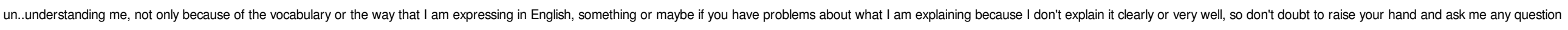
that you have, ok? (Accounting Lecturer 1: 5.25-6.07)

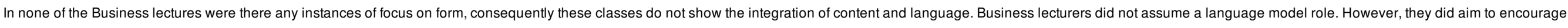
students' English production, stressing that accuracy was not a concern.

L. I don't worry about how you write because I'm not going to XXX level of English because....You can express as you want. But you can express it in English! (Accounting Lecturer 1: 17.95-18.15)

Some inaccuracies were found in the lecturers' discourse, which often went unrepaired, as in the following example from Accounting:

L This is the relationship between economic growth and total [...] activity. okey/ There are a correlation...Are you agree with me/ (Accounting Lecturer 2: 9.05-9.21) 


\section{elsevier_ESP_741}

Lecturers also used compensation strategies, such as the occasional use of L1, or the careful planning of discourse with elaborated definitions and support material (e.g., PowerPoint).

The confirmation checks by the Law lecturer signalled overt communication breakdowns, as in the explanation below:

$\mathrm{L} \ldots$...between legal systems in the world/...is that clear/

S1 yesl

S2 nol

$L$ the comparison between legal systems in the world

(Law: 21.44-22.07)

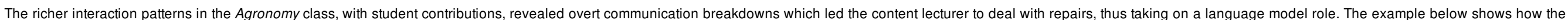
lecturer asks the student for clarification, which leads to a repair exchange on the mispronunciation of <source>.

S: we need a high voltage + surs +

L: high voltage/

S: + surs+l

$\mathrm{L}:+$ +surst/

S: +surse+

$L:+$ ah + / source

(Agronomy. 4.04-4.10)

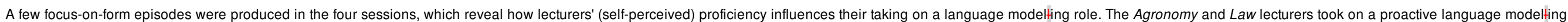
role when comprehensibility was at risk. In contrast, the Accounting lecturers appeared to be less active in language modelling, congruent with their lower proficiency.

\subsection{Participants' perceptions of CLIL from focus group discussions}

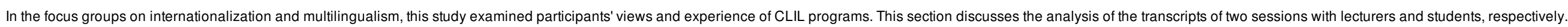

\subsubsection{Lecturers' perceptions}

The analysis of the lecturers' focus group discussion yielded the following topics: the benefits and challenges of CLIL, especially regarding language proficiency; and the role of CLIL versus ESP.

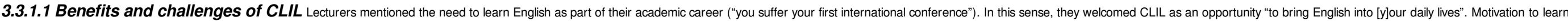

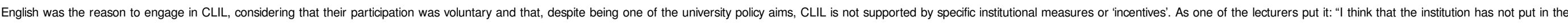

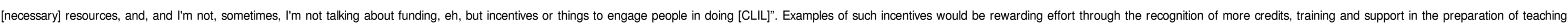
materials.

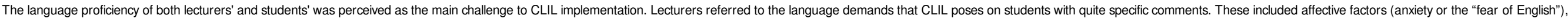

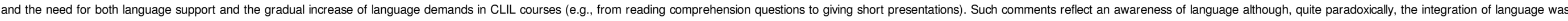

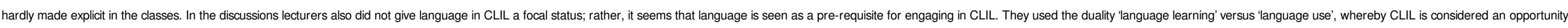
for authentic language use: "Il's not so much that they [students] learn the language (although they learn technical vocabulary), but that they lose the fear of using the language, that they feel the need to use the language." 


\section{elsevier_ESP_741}

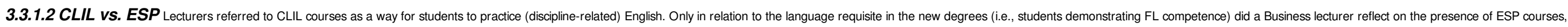
with a more favorable opinion towards CLIL than to ESP, as shown in the comments below:

"I think the way to introduce the third language is by doing a course in English, not what we're doing, which is doing English (i.e. ESP courses)"

"I think that with an English course we're not introducing this competence"

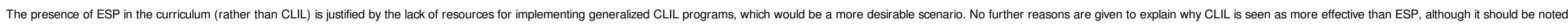

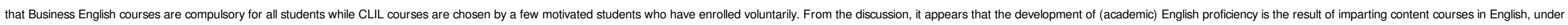
the responsibility of content lecturers, while no references are made to ESP courses or to the collaboration of language specialists for the integration of language in content courses.

\subsubsection{Students' perceptions}

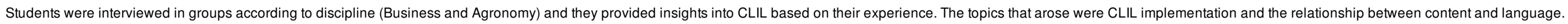

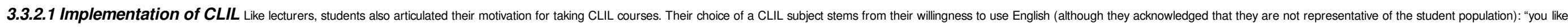
English, you want to learn... It's new". They showed positive views towards CLIL, expressing language benefits like specific vocabulary/discourse, the development of fluency, and losing their fear of speaking in public.

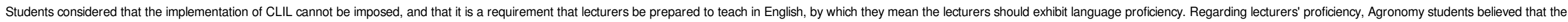

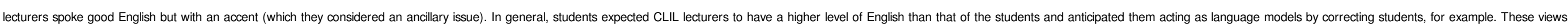
coincide with the class observations, in which the Agronomy lecturer acted as a model and repaired students' contributions.

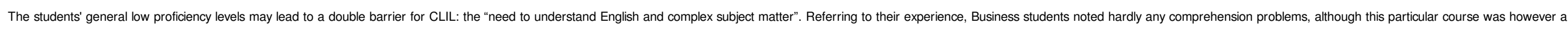

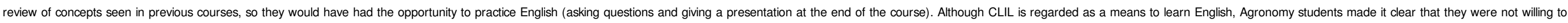
sacrifice content for the sake of language learning: "You need to become an engineer, not a «half-engineer» with English - you can learn English outside university, but not calculus."

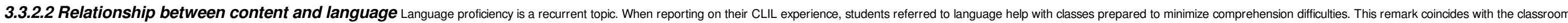
data as, for example, the Accounting classes observed included detailed visual support. Agronomy students mentioned that the lecturer used a combination of materials in Catalan and English.

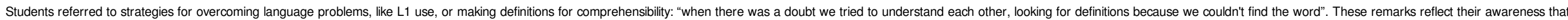

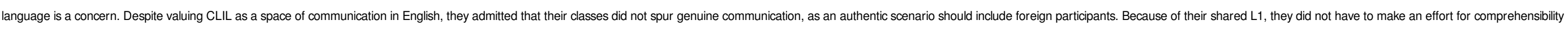
or strive for accuracy. They fell back on the $L 1$ as shortcuts to communication:

"What I probably found most difficult was when we gave the oral presentation. Speaking in front of the class and expressing yourself well, as you knew they understood you perfectly. Well if you said something in Catalan [code-switching/mixing], well, they understood you.

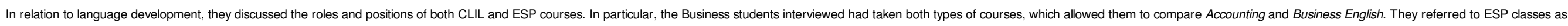
being hard for students, even though they considered them to be at the same level as English courses at secondary school:

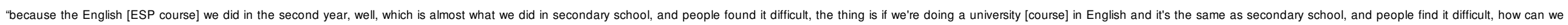
move on?"

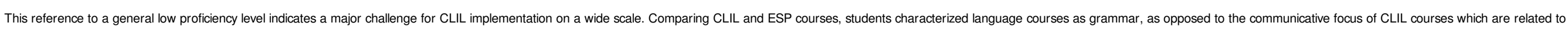

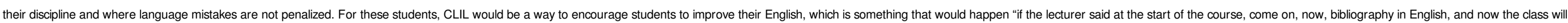
be in English".

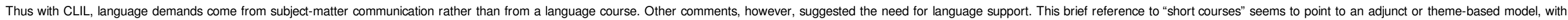
language instruction closely linked to content: 
"Of course, that is the point, for those who did English, English classes, grammar or that... for example we do short courses, but in a class, the same as for "Accounting", a class of "marketing", in English, we'll do a short course..."

Therefore, students' comments on content and language point to some challenges for CLIL (mainly low proficiency), as well as to some possibilities for their integration based on the use of English for genuine communicative needs related to their discipline.

\subsection{General views on CLIL expressed through a questionnaire}

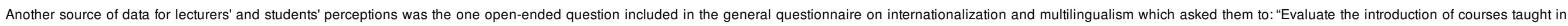
English and French at UdL through the "Multilingual Plan" (not language courses, but courses taught in these foreign languages)".

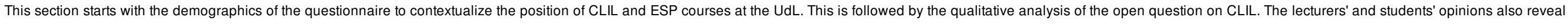

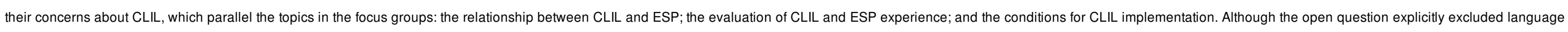
courses, some participants referred to ESP which provided valuable information on the relationship between language and content.

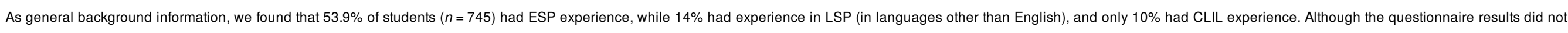

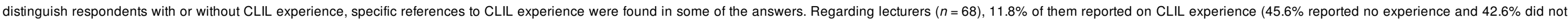
answer the question). These figures confirm that CLIL is a new phenomenon in the institution and that there is a tradition of ESP.

\subsubsection{Relationship between CLIL and ESP}

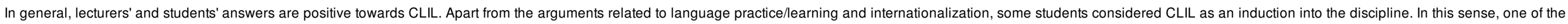
views that emerged is a definition of CLIL as a kind of ESP:

"It's positive for students as this is the language required in today's labor market, so it's important to learn it and it's good to have classes in English so that students can improve their knowledge of English and in the technical aspects of their discipline." [S. 157]

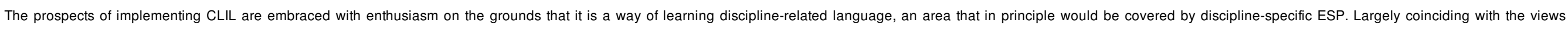

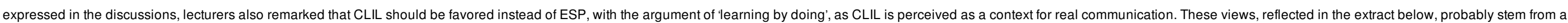
stereotyped view of language courses as not communicative. The distinction between "didactic" and "applied" courses is quite revealing, as it most likely refers to CLIL versus ESP:

"It is positive, a didactic course is not the same as an applied course, where students face a "real" use of the language in question." [L. 16]

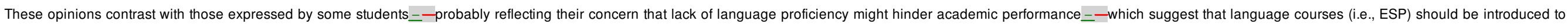
complement content classes taught in English:

"I think that it is the best way to learn a language with a kind of "linguistic immersion". But it would also be necessary to offer language courses to learn it well." [S. 8]

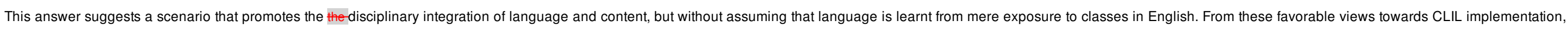
some lessons can be derived for ESP teaching: heightened student motivation (out of the perception that learning English is essential), and an ESP model closely linked to discipline-specific content and practices.

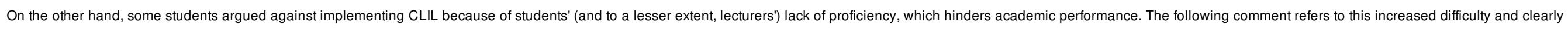
separates language learning from content learning by suggesting the incorporation of language courses (i.e., ESP) rather than courses taught in English:

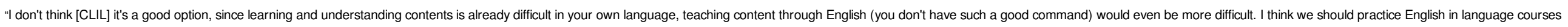

rather than [in] other courses." [S. 188]

\subsubsection{Evaluation of CLIL and ESP experience}

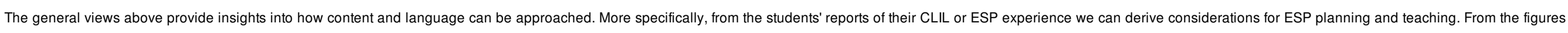
presented at the beginning of this section, only a few participants had had experience of CLIL, whereas about half of the students had had experience of ESP. 


\section{elsevier_ESP_741}

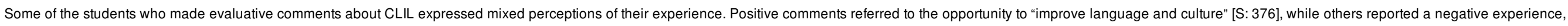

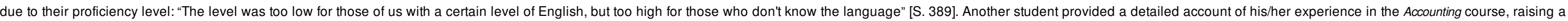

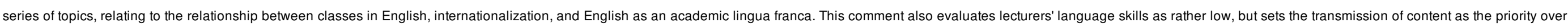
language:

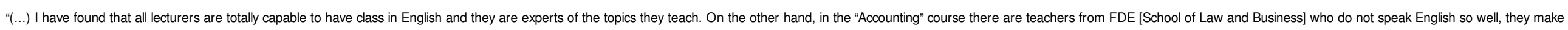

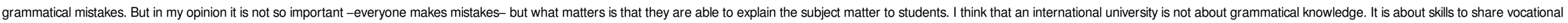

knowledge between lecturers from more than one country and students from more than one country." [S. 696]

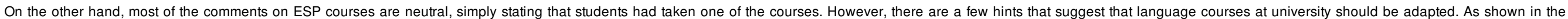

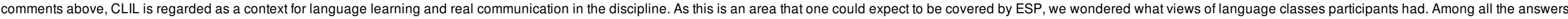

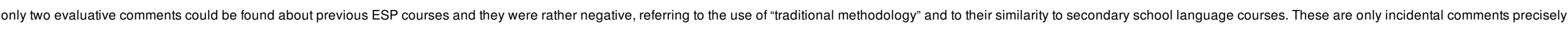

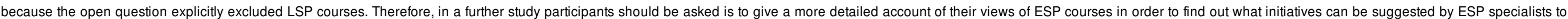
promote discipline-specific communication.

\subsubsection{Conditions for the implementation of CLIL}

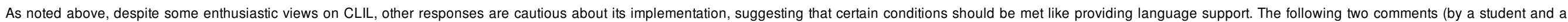

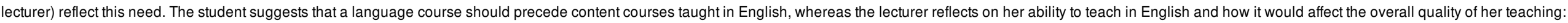

"I think it's quite a radical change, as in secondary school the level was not high, and here it's very difficult. I think there should be an English language course and little by little introduce it [the English language] in different courses." [S. 40]

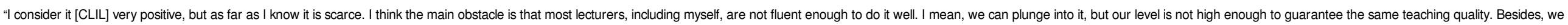
don't have anyone to help us correct our mistakes. It would be a good idea to have a language support person while we're doing our classes in English so that at the end we could evaluate it and correct the errors." [L. 43]

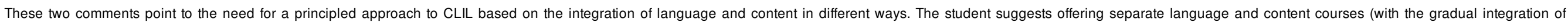

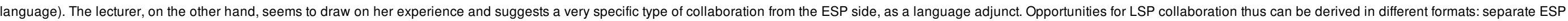
courses as a preparation for further courses taught in English; gradually integrate content and language in content courses; or provide language consultancy/support for content lecturers teaching in English.

\section{Discussion and implications}

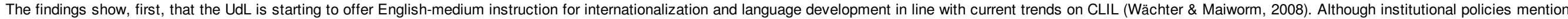

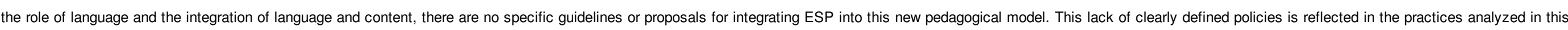

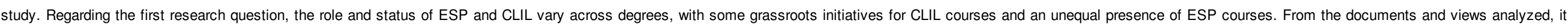

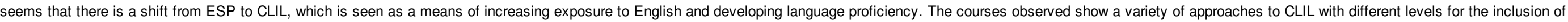

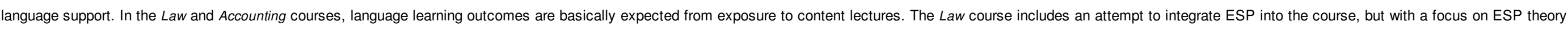

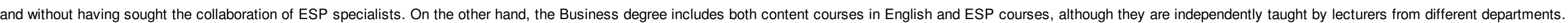
The Agronomy course, based on the collaboration between a content lecturer and a language specialist, can be classified as an adjunct course with explicit language learning objectives and outcomes.

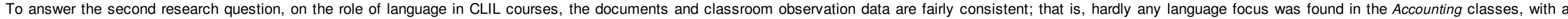

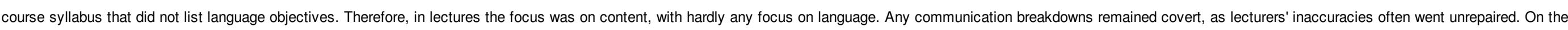

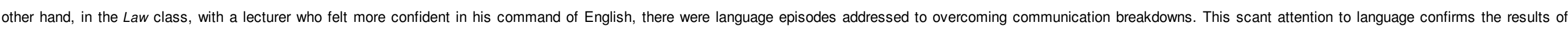

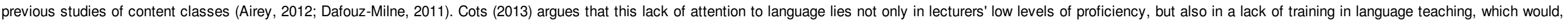
in turn, involve a lack of language awareness. 


\section{elsevier_ESP_741}

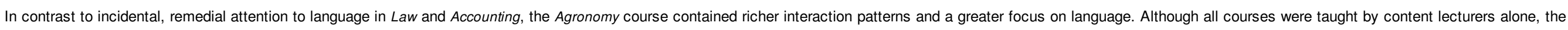

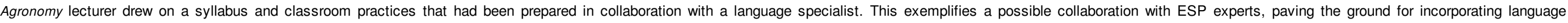

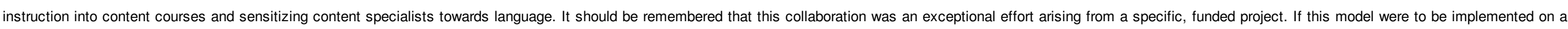

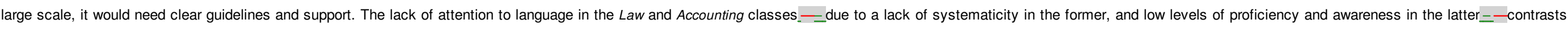

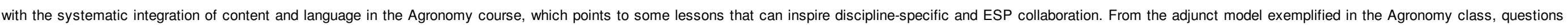

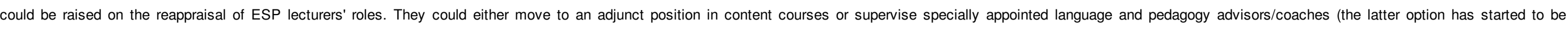

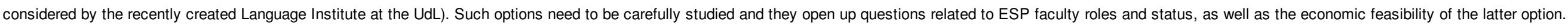

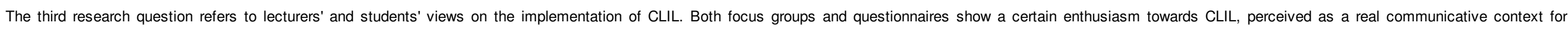

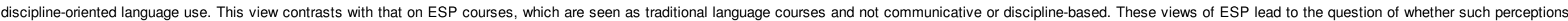

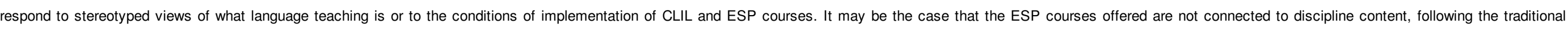

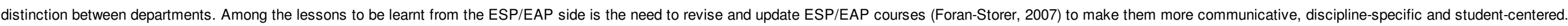

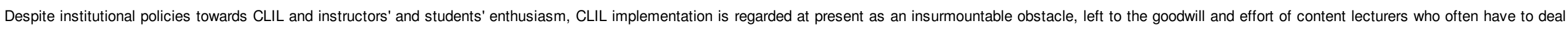

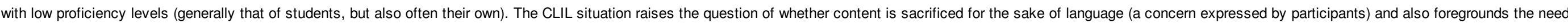

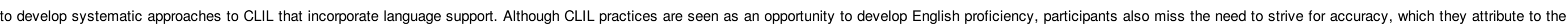

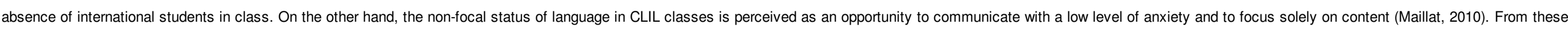

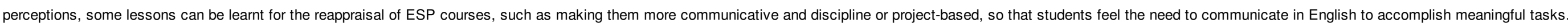

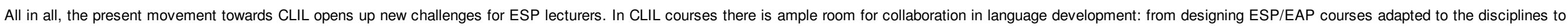

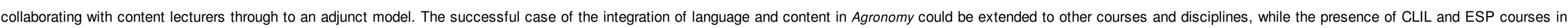

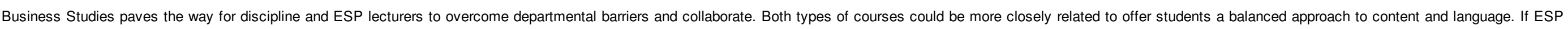
courses are to be seen as meaningful and necessary, needs analysis has to be reinstated at the centere of course design_—one of the "key stages in ESP" according to Dudley-Evans and St. John (1998).

\section{Conclusions}

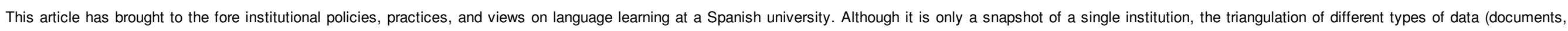

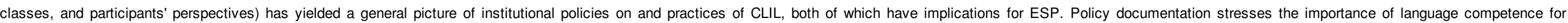

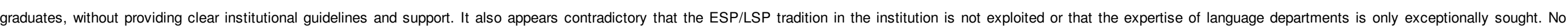

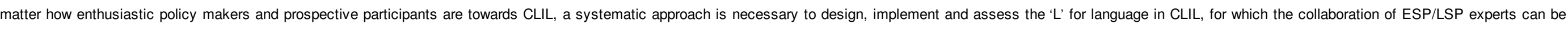

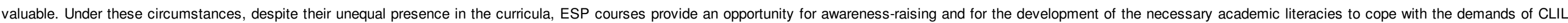

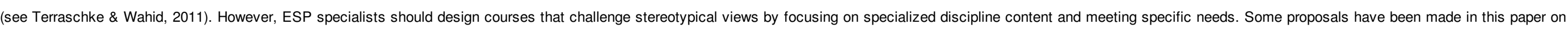
an adjunct ESP model in content courses and the design of ESP courses informed by stakeholders' needs.

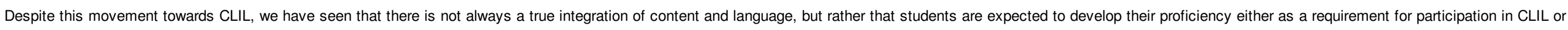

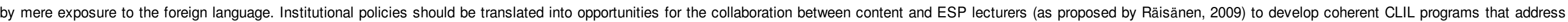

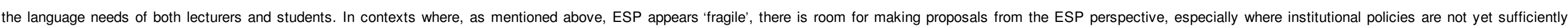

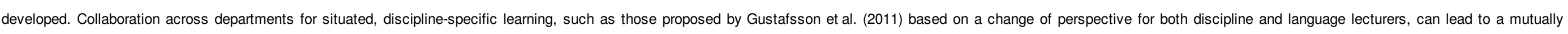

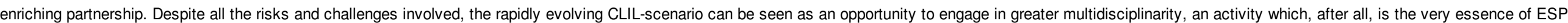

\section{Uncited reference}

Brinton and Holten, 2001; University of Lleida, 2010; Wächter, 2008. 


\section{elsevier_ESP_741}

\section{References}

Airey J., "I don't teach language." The linguistic attitudes of physics lecturers in Sweden, In: Smit U., et al., (Eds.), Integrating content and language in higher education, 2012 , John Benjamins; Amsterdam, 64-79.

Allwright D. and Bailey K., Focus on the language classroom, 1991, Cambridge University Press; Cambridge, England.

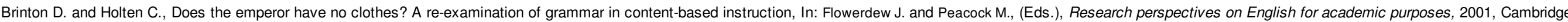

University Press; Cambridge, England, 239-251.

Brinton D., Snow M. and Wesche M., Content-based second language instruction, 1989, Heinle \& Heinle; Boston, MA.

Coleman J., English-medium teaching in European higher education, Language Teaching 39, 2006, 1-14.

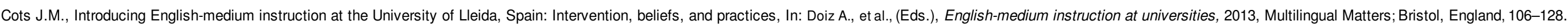

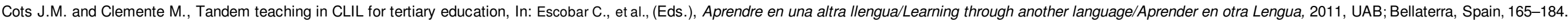

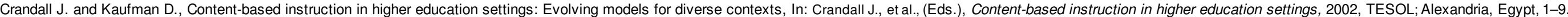

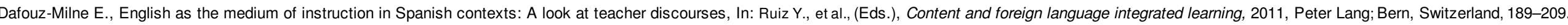

Dalton-Puffer C., Discourse in content and language integrated learning (CLIL) classrooms, 2007, Amsterdam, Philadelphia.

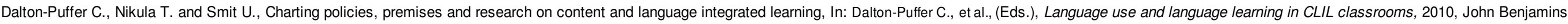
Amsterdam, 1-19.

Denzin N. and Lincoln Y., Handbook of qualitative research, 1994, Sage Publications; London.

Dudley-Evans T. and St. John M., Developments in English for specific purposes: A multi-disciplinary approach, 1998, Cambridge University Press; Cambridge, England.

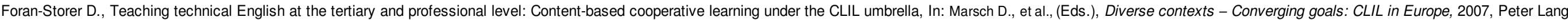
Frankfurt, Germany, 309-317.

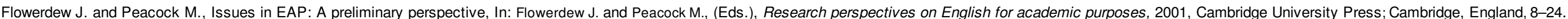

Greere A. and Räsänen A., Report on the LANQUA subproject on content and language integrated learning - Redefining CLIL: Towards multilingual competence, 2008, Retrieved from http://www.irre-

vda.org/utilita/deposito/UserFiles/File/LANQUA-report.pdf.

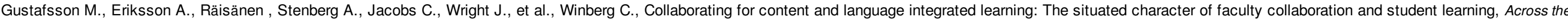
Disciplines 8 (3), 2011, Retrieved from http://wac.colostate.edu/atd/clil/gustafssonetal.cfm.

Hutchinson T. and Waters A., English for specific purposes: A learning-centred approach, 1987, Cambridge University Press; Cambridge, England.

Hyland K., Specificity revisited: How far should we go now?, English for Specific Purposes 21, 2002, 385-395.

Hyland K., "The past is the future with the lights on": Reflections on AELFE's 20th birthday, Ibérica 24, 2012, $29-42$.

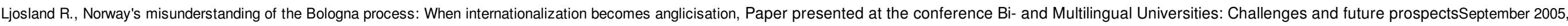

Helsinki University, Retrieved from http://www.palmenia.helsinki.fi/congress/bilingual2005/presentations/Ljosland.pdf.

Lyster R., Learning and teaching languages through content: A counterbalanced approach, 2007, John Benjamins; Amsterdam.

Maillat D., The pragmatics of L2 in CLIL, In: Dalton-Puffer C., et al., (Eds.), Language use and language learning in CLIL classrooms, 2010, John Benjamins; Amsterdam, 39-58. 


\section{elsevier_ESP_741}

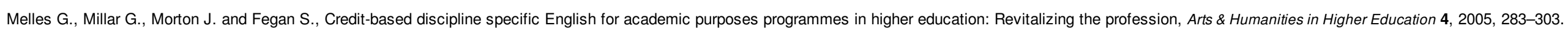

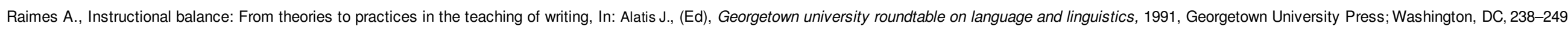

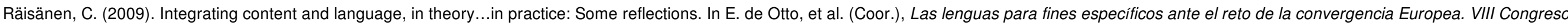
Internacional AELFE (pp. 33-41). La Laguna, Spain: Servicio de Publicaciones.

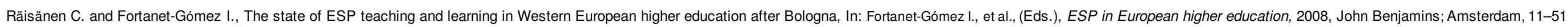

Swales J., Barks D., Osterman A. and Simpson R., Between critique and accommodation: Reflections on an EAP course for masters of architecture students, English for Specific Purposes 20 (1), 2001, 439-458.

Terraschke A. and Wahid R., The impact of EAP study on the academic experiences of international postgraduate students in Australia, Journal of English for Academic Purposes 10 (3), $2011,173-182$.

University of Lleida, Programa d'Internacionalització, 2006, Retrieved from http://www.udl.cat/export/sites/UdL/serveis/ori/Fitxers_descxrrega/Pla_internacionalitzacio2.pdf.

University of Lleida, Pla director de la docència de la UdL, 2007, Retrieved from https://cv.udl.cat/access/content/group/docsvd/Pla\%20director\%20de\%20docencia.pdf

University of Lleida, Política lingüística de la UdL, 2008, Retrieved from http://web.udl.es/rectorat/sg/bou/bou101/acord153.htm.

University of Lleida, Normativa d'Acreditació de la tercera llengua en els estudis de grau, 2010, Retrieved from http://web.udl.es/rectorat/sg/bou/bou123/acord224.htm.

Watson-Gegeo K., Ethnography in ESL: Defining the essentials, TESOL Quarterly 22 (4), 1988, 575-592.

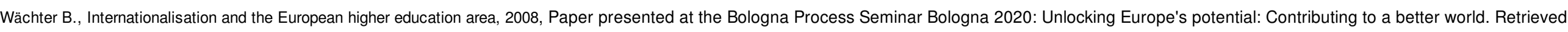

from http://www.ond.vlaanderen.be/hogeronderwijs/bologna/BolognaSeminars/Ghent2008_background_documents.htm.

Wächter B. and Maiworm F., English-taught programmes in European higher education: The picture in 2007, 2008, Lemmens; Boon.

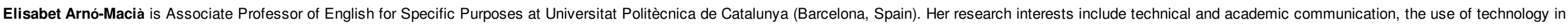
languages for specific purposes, and English-medium instruction in higher education.

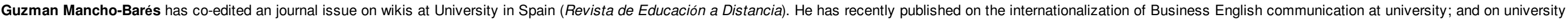
teaching staff's attitudes to internationalization and multilingualism in two bilingual communities in Spain.

\section{Footnotes}

${ }^{2}$ For details on the Bologna process see: http://ec.europa.eu/education/higher-education/bologna_en.htm.

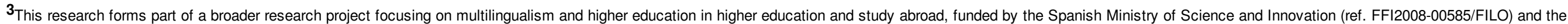
Spanish Ministry of Economy and Competitiveness (ref. FFI2012-35834).

${ }^{4}$ The Common European Framework of Languages is an initiative by the European Council to design a transparent system for describing levels of language proficiency as an aid for language teaching and assessment: http://www.coe.int/t/dg4/linguistic/cadre1_en.asp.

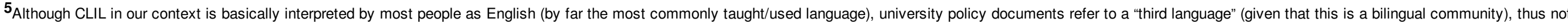
excluding other languages. For this reason, the question in the survey explicitly adds French, which is the other LSP offered at the university.

Highlights

- Shift from ESP to CLIL courses in curricula.

- Policy stresses foreign language competence, but no institutional support is provided. 


\section{elsevier_ESP_741}

- Collaboration with ESP teachers in language development is needed in CLIL courses.

- Reappraisal of ESP courses: more oriented towards discipline communication needs.

\section{Queries and Answers}

Query: The citation 'Räisänen \& Fortanet, 2008' has been changed to match the author name/date in the reference list. Please check, and correct if necessary.

Answer: Please, follow the attachment for answers.

Query: One parenthesis has been added to balance the delimiters. Please check that this was done correctly, and amend if necessary.

Answer: Please, follow the attachment for answers.

Query: Note that of the two sets of Table 1 provided, we have followed the Table that has been provided separately in the doc 'Table 1.docx'. Please check, and correct if necessary.

Answer: Please, follow the attachment for answers.

Query: If possible, please provide doi/web link for all references available online/magazines/newspapers

Answer: Please, follow the attachment for answers.

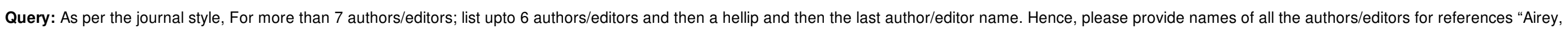

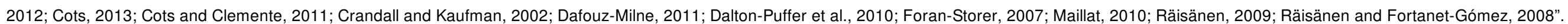

Answer: Please, follow the attachment for answers.

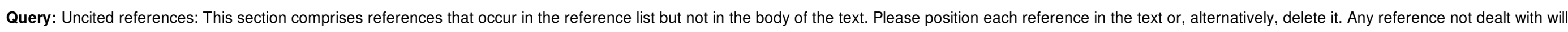
be retained in this section. Thank you.

Answer: Please, follow the attachment for answers.

Query: Please confirm that given names and surnames have been identified correctly.

Answer: Please, follow the attachment for answers. 